\title{
The calcareous concretions (cementsten) in the Fur Formation (Paleogene, Denmark): isotopic evidence of early diagenetic growth
}

\author{
GUNVER KRARUP PEDERSEN \& BJøRN BUCHARDT
}

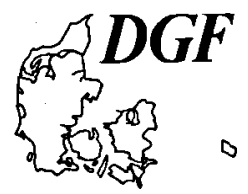

\begin{abstract}
Pedersen, G.K. \& Buchardt, B.: The calcareous concretions (cementsten) in the Fur Formation: isotopic evidence of early diagenetic growth. Bulletin of the Geological Society of Denmark, Vol. 43, pp. 78-86. Copenhagen 1996-07-14. https://doi.org/10.37570/bgsd-1996-43-09
\end{abstract}

The Paleogene Fur Formation in northwestem Denmark is a c. $60 \mathrm{~m}$ thick clayey diatomite that comprises calcite concretions, the so-called cementsten. The diatomite is interbedded with 179 isochronous and recognizable layers of volcanic ash, which demonstrate that the concretions occur at six stratigraphic levels throughout the Fur Formation. The concretions formed through precipitation of calcite in the pore space within the diatomite or the ash layers. Carbon and oxygen isotope compositions were determined on the concretionary calcite. $\delta^{13} \mathrm{C}$ values around $-20 \%$ o to $-16 \%$ o indicate that most (bi)carbonate was of bacterial origin, formed through metabolization of organic matter by sulphate reduction. $\delta^{18} \mathrm{O}$ values of $-1 \%$ o to $-3 \%$ indicate that calcite precipitated at temperatures corresponding to those measured in contemporaneous marine shell material. It is specu-lated that rare blooms of phytoplankton made the six stratigraphic levels the pre-ferred sites of nucleation of the concretions.

Gunver Krarup Pedersen \& Bjørn Buchardt, Geological Institute, University of Copenhagen, Øster Voldgade 10, DK-1350 Copenhagen K, Denmark. March 21st, 1996.

\section{Introduction}

The Upper Paleocene to Lower Eocene Fur Formation (Pedersen \& Surlyk 1983) is an approximately $60 \mathrm{~m}$ thick marine diatomite (mo-clay) exposed in a geographically restricted area in northwest Jutland (Fig. 1). The formation includes 179 isochronous layers of volcanic ash, which have facilitated the establishment of a detailed local stratigraphy (Bøggild 1918, Gry 1940). Several horizons rich in calcareous concretions, locally named cementsten (cementstone), are found in the formation, especially in its upper part.

The concretions formed by precipitation of calcite in the pore space of diatomite, in the ash layers or in both. Concretionary growth took place at well defined stratigraphic levels throughout the depositional basin as proven by ash layer stratigraphy (Bøggild 1918, Pedersen \& Surlyk 1983). The concretions are known for their content of rare and extremely well preserved fossils (Pedersen, Pedersen \& Noe 1994).
The origin of the calcareous concretions was first discussed by Bøggild (1918), who suggested that organisms with calcareous shells had been dissolved and reprecipitated as calcareous concretions. He speculated that episodic proliferation of organisms with calcareous shells made certain stratigraphic levels the sites of nucleation of the concretions.

The present study has been carried out in order to identify the source of the carbonate and the relative age of carbonate precipitation. We have determined the stable isotope composition of concretionary carbonate and compared the occurrence of concretions to sedimentological observations. 
Fig. 1. Location map of Fur Formation outcrops mentioned in the text.

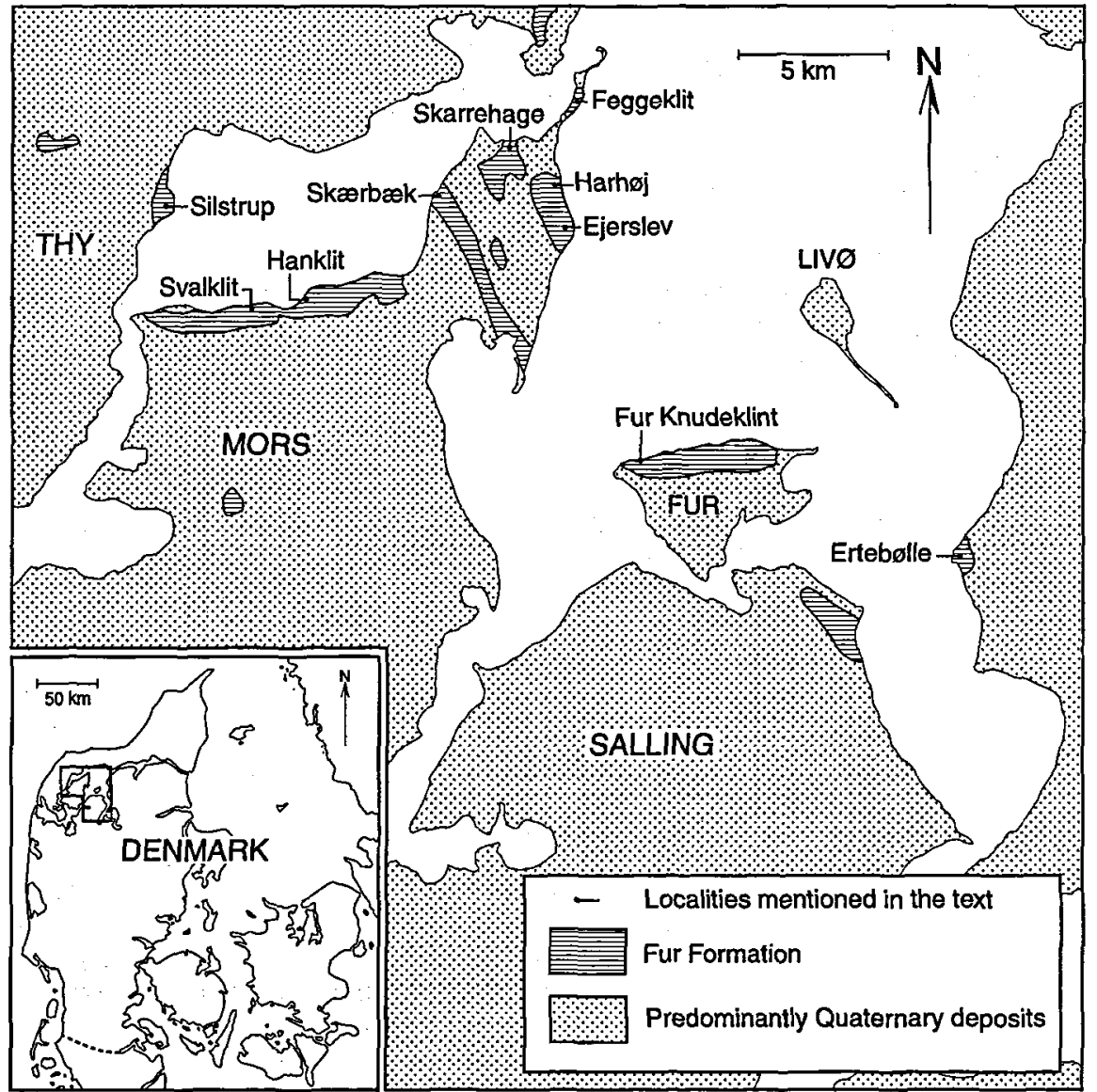

\section{Geological setting}

The Late Paleocene palaeogeography of the North Sea region is envisaged as an enclosed marine basin connected northwards to the oceans through a relatively narrow seaway between Norway and Greenland. Probably, there was no marine circulation through the British Channel and a volcanic province between Scotland and Greenland at times created the 'Thulean Landbridge' across the Atlantic Ocean (Ziegler 1990). The North Sea Basin and the Danish Basin may thus have formed restricted marine basins, possibly with relatively deep water (Heilmann-Clausen 1995). The North Atlantic volcanic province is interpreted as the eruption site of the ash layers exposed in the Fur Formation and recorded in wells in the North Sea and the Irish Sea (Knox 1984, Knox, Corfield \& Dunay 1996).

The Paleogene sedimentary succession in Denmark comprises fine-grained marine deposits, recently reviewed by Heilmann-Clausen, who defines six sedimentary cycles separated by unconformities, which frequently are heavily glauconized (Heilmann-Clausen 1995). The second cycle comprises the Fur and Ølst Formations characterized by different sedimentary facies but demonstrated to be co-eval on basis of the ash-layer stratigraphy (Andersen 1937). Both formations are of either latest Paleocene or earliest Eocene age (Heilmann-Clausen 1995).

\section{Sampling and methods}

Detailed sedimentological logs have recorded the type and distribution of the Fur Formation concretions, their thickness, the sedimentary facies of the diatomite, and the number of ash layers - if any - in the concretions (Bøggild 1918, Pedersen \& Surlyk 1983). Material for the present study was collected from coastal outcrops and diatomite pits in the western Limfjord area. Several stratigraphic levels with concretions were sampled. Variations between concretions from a single stratigraphic level have been studied in concretions around ash layers +22 to +35 , which also yielded material for detailed sampling across individual concretions.

Laboratory sampling was performed by drilling of 5 $\mathrm{mm}$ diameter holes in the central part of fresh, unweathered samples. The mineralogy was investigated 
by X-ray diffraction. Carbonate content (wt\%) was determined volumetrically from the amount of carbon dioxide evolved during preparation for isotopic measurements. Mass spectrometric determination of carbon and oxygen isotope composition of the calcareous phase was performed on carbon dioxide prepared by dissolution in vacuo at $25.0^{\circ} \mathrm{C}$ in $99 \%$ phosphoric acid (McCrea 1950). The mass spectrometry was performed on a MAT 250 triple collector instrument at the Stable Isotope Laboratory at the Geological Institute, University of Copenhagen. Results are reported as $\delta^{13} \mathrm{C}$ and $\delta^{18} \mathrm{O}$-values relative to the PDB standard. Reproducibility is better than $\pm 0.05 \%$ on the $\delta$-scale for both isotope ratios.

\section{Observations and results}

\section{Sedimentology}

The sedimentology of the Fur Formation has been described by Pedersen (1981) and Pedersen \& Surlyk (1983). The high percentage of diatom frustules (about $65 \mathrm{wt} \%$ ) suggests that abundant organic matter was deposited though little is preserved in the diatomite today. Most of the organic matter was metabolized through oxygen consuming processes, and the sea floor thus constituted a low-oxygen environment throughout the entire period of diatomite deposition. The boundary between oxygen-consuming and sulphatereducing bacteria probably lay very close to the water-sediment interface. Its position varied in response to changes in the rates of sediment accumulation or bottom water circulation. Metabolization of organic matter by sulphate-reducing bacteria continued to a depth below the sediment-water interface governed by amount of organic matter and the rate of sulphate diffusion from the sea water.

Pedersen $(1978,1981)$ distinguished three facies types in the Fur Formation (Fig. 2): 1) Laminated diatomite deposited under anoxic bottom water (less than $0.1-0.3 \mathrm{ml} \mathrm{O} / 1$ ) in which a benthic fauna could not exist, 2) weakly laminated diatomite formed through intermittent burrowing by a sparse benthic fauna under slightly more oxic bottom water, and 3) structureless diatomite formed as a product of complete bioturbation by a benthic fauna of presumably soft-bodied organisms indicating oxic bottom water (more than $0.5 \mathrm{ml} \mathrm{O}_{2} / 1$ ). Consequently small changes in oxygen content produced strongly contrasting sedimentary facies, i.e. laminated or structureless diatomite.

\section{Description of concretions}

The calcareous concretions in the Fur Formation include both diatomite and ash layers. Although levels with structureless diatomite do contain concretions,

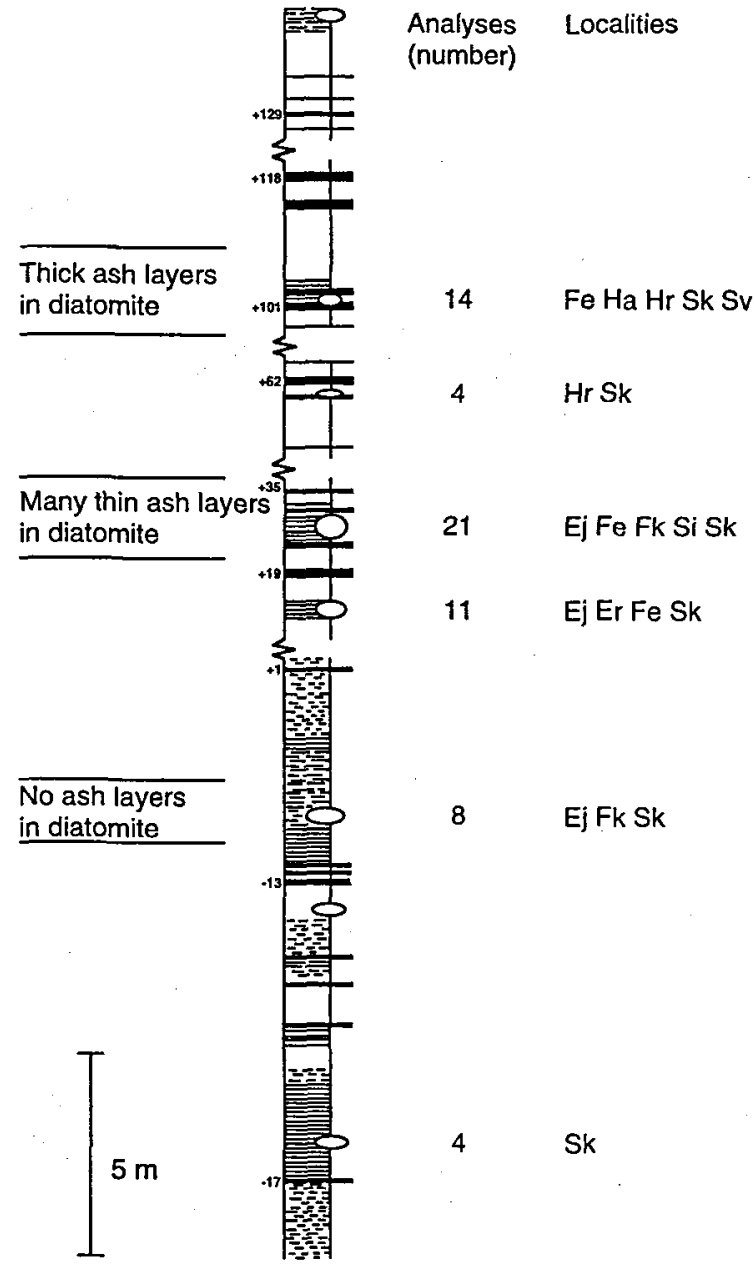

Fig. 2. Sedimentological log showing the distribution of concretions and the position of the samples. The degree of lamination is indicated. Note that the concretions are not restricted to specific sedimentary facies. Ej: Ejerslev, Er: Ertebølle, Fe: Feggeklit, Fk: Fur Knudeklint, Ha: Hanklit, Hr: Harhøj, Si: Silstrup, Sk: Skarrehage, Sv: Svalklit.

they preferentially occur in laminated diatomite. Regional studies of the Fur Formation shows that the concretions are consistently present at six stratigraphic levels: below ash layer -13 (structureless diatomite), between ash layers -11 and +1 (laminated or weakly laminated diatomite), below ash layer +19 (laminated diatomite), between ash layers +22 and +35 (laminated diatomite), within ash layers +101 to +102 (weakly laminated diatomite) and below ash layer +135 (laminated or weakly laminated diatomite). Locally concretions may occur above ash layer -17 (laminated diatomite) or between ash layers +60 and +62 (structureless diatomite) (Bøggild 1918, Pedersen \& Surlyk 1983) (Fig. 2). The volcanic ash is dominantly of sand size and the ash layers are graded. Permeability was 


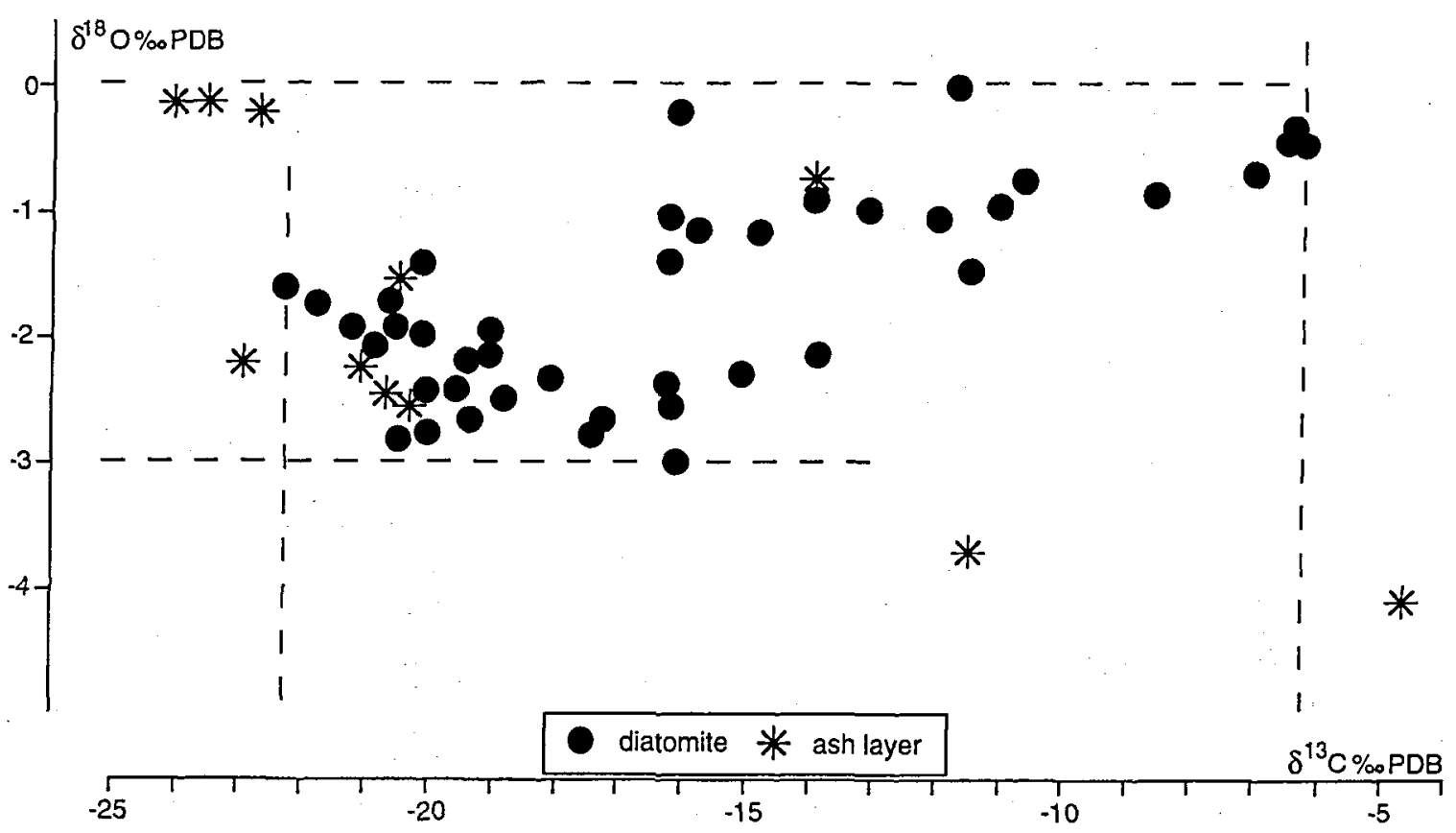

Fig. 3. Plot of the measured values of $\delta^{13} \mathrm{C}$ and $\delta^{18} \mathrm{O}$. The number of analyses is higher than the number of samples. Some samples have provided more than one analysis as a check of variability within one lithology type or between lithologies, as well as effects of weathering. The points are scattered but a regression analysis shows that no trend exists. Note that the range of $\delta^{13} \mathrm{C}$ values is larger than the range of $\delta^{18} \mathrm{O}$ values.

generally higher than in the finer grained diatomite and horizontal permeability exceeded vertical permeability within the ash layers. In the laminated or weakly laminated diatomite the horizontal permeability also exceeds the vertical permeability.

Concretions nucleated and grew in diatomite as frequently as in ash layers indicating that neither differences in lithology nor in permeability of the host sediment initiated the growth of the concretions. This is supported by the sedimentological studies which document that the Fur Formation comprises numerous levels devoid of concretions but lithologically similar to the levels of nucleation of the concretions. Concretions sometimes contain fossils in the centre, but fossils are just as frequently found outside the concretions and nucleation did not therefore have any relation to decomposition of organic tissue. It is concluded that the concretions are genetically linked to distinct stratigraphic levels rather than to certain sedimentary facies or the distribution of fossils.

Most concretions are ellipsoidal and frequently reach a horizontal diameter of one metre. Locally, concretions have annealed into layers up to half a metre in thickness and with a lateral extension of several hundred metres. The concretions formed before any major compaction of the diatomite, and the primary lamination of diatomite and ash layers can be followed from sediment to concretion. Also, the almost perfect, threedimensional preservation of fossils in the concretions shows the precompactional character of the concretions.

\section{Mineralogy}

X-ray diffraction data demonstrate that the concretionary carbonate exclusively is low magnesium calcite. In thin sections, the calcitic phase is seen to be fine crystalline and to fill the pore space of the host rock without obvious displacement structures. Some concretions contain an earlier diagenetic mineral phase of unknown composition now replaced by calcite. This phase, which has been described as pseudogayllusite by Pedersen et al. (1994), forms large (more than 20 $\mathrm{cm}$ ), euhedral crystals antedating the growth of the calcareous concretions. The crystals resemble glendonites, which have been interpreted as pseudomorphs after the mineral ikaite $\left(\mathrm{CaCO}_{3} \cdot 6 \mathrm{H}_{2} \mathrm{O}\right)$ by Shearman and Smith (1985).

\section{Carbonate content}

The percentage of $\mathrm{CaCO}_{3}$ is $75-90 \mathrm{wt} \%$ in the centre of the concretions, and decreases to about 70-90 wt\% near the margins (Table 1). In precompactional concretions, the cement content in the central parts reflects initial porosity of the host sediment (Raiswell 1971). 
Table 1. Geochemical results

\begin{tabular}{|c|c|c|c|c|c|}
\hline Sample & $\begin{array}{l}\text { Location, } \\
\text { numbers refer to ash layers }\end{array}$ & $\begin{array}{l}\text { Host lithology, } \\
\text { place in concretion }\end{array}$ & $\begin{array}{l}\mathrm{CaCO}_{3} \\
\mathrm{wt} \%\end{array}$ & $\begin{array}{l}\delta^{13} \mathrm{C} \\
\% o^{1)}\end{array}$ & $\begin{array}{l}\delta^{18} \mathrm{O} \\
\% o^{11}\end{array}$ \\
\hline cem. 1-1 & Fur Knudeklint, +22 to +35 & diatomite, margin & 73 & -20.23 & -1.99 \\
\hline cem. $1-2$ & same & diatomite, margin & 71 & -20.62 & -1.93 \\
\hline cem. $1-3$ & same & diatomite, centre & 80 & -17.48 & -2.77 \\
\hline cem. $1-4$ & same & diatomite, centre & 79 & -17.48 & -2.60 \\
\hline cem. $1-5$ & same & ash layer : & 34 & -11.54 & -3.70 \\
\hline cem. $1-6$ & same & diatomite, centre & 77 & -16.36 & -2.40 \\
\hline cem. $\quad 1-7$ & same & diatomite, marg., weathered & 82 & -16.15 & -3.00 \\
\hline cem. $2-1$ & Ejerslev, below +19 & diatomite & 76 & -20.46 & -2.83 \\
\hline cem. $3-1$ & Svaleklit, loose, $+101 /+102$ & diatomite, laminated & 80 & -20.39 & -1.41 \\
\hline cem. $3-2$ & same & ash layer & 44 & -23.60 & -0.15 \\
\hline cem. $3-3$ & same & ash layer & 43 & -24.07 & -0.11 \\
\hline cem. $4-1$ & unknown & diatomite, lam., centre & 74 & -20.93 & -2.07 \\
\hline cem. $5-1$ & Fur Knudeklint & radiating crystals & 98 & -22.78 & -2.81 \\
\hline cem. $6-1$ & Fegge, $1 \mathrm{~m}$ below +19 & diatomite, dark & 86 & -16.16 & -0.22 \\
\hline cem. $6-2$ & same & diatomite, pale & 92 & -13.97 & -2.15 \\
\hline cem. $6-3$ & same & diatomite, dark & 83 & -15.12 & -2.30 \\
\hline cem. $7-1$ & Fegge, +22 to +35 & diatomite, lam. & 76 & -16.19 & -2.57 \\
\hline cem. $8-1$ & Skarrehage, -11 to +1 & diatomite, centre & 83 & -8.60 & -0.88 \\
\hline cem. 9-1 & Ejerslev, -11 to +1 & diatomite, lam., centre & 77 & -20.15 & -2.77 \\
\hline cem. $10-1$ & Fur Knudeklint, -11 to +1 & diatomite & 78 & -21.33 & -1.87 \\
\hline cem. 12-1 & Skarrehage, +22 to +35 & diatomite, lam. & n.d. & -11.73 & -0.03 \\
\hline cem. 13-1 & Kås Hoved, loose & diatomite, lam. & n.d. & -20.40 & -0.98 \\
\hline cem. $13-2$ & same & ash layer, top & n.d. & -19.86 & -0.86 \\
\hline cem. 13-3 & same & ash layer, bottom & n.d. & -17.62 & -0.88 \\
\hline cem. $15-1$ & Ertebølle, loose, below +19 & diatomite, lam. & 89 & -22.30 & -1.61 \\
\hline cem. $17-1$ & Ertebølle, loose, below $+19 ?$ & diatomite, lam., marg. & 92 & -20.62 & -1.71 \\
\hline cem. $17-2$ & same & diatomite, lam., centre & 90 & -21.83 & -1.73 \\
\hline cem. 18-1 & Erteb $ø l l e$, loose, $+101 /+102 ?$ & ash layer, bioturbated & 40 & -20.51 & -1.59 \\
\hline cem. $18-2$ & same & diatomite, bioturbated & 82 & -19.02 & -1.97 \\
\hline cem. $18-3$ & same & diatomite, bioturbated & 82 & -19.11 & -2.29 \\
\hline cem. 19-1 & Skarrehage, $+101 /+102$ & ash layer, centre & 46 & -11.52 & -1.14 \\
\hline cem. 21-1 & Skarrehage, -17 & diatomite, lam., marg. & 78 & -6.27 & -0.47 \\
\hline cem. $21-2$ & same & diatomite, lam., centre & 80 & -6.52 & -0.45 \\
\hline cem. $21-3$ & same & diatomite, lam., centre & 78 & -7.02 & -0.71 \\
\hline cem. $21-4$ & same & diatomite, lam., marg. & n.d. & -6.44 & -0.38 \\
\hline cem. 22-1 & Hanklit, $+101 /+102$ & diatomite, lam., weath. & 85 & -16.25 & -1.40 \\
\hline cem. $22-2$ & same & ash layer, bottom & 40 & -22.71 & -0.24 \\
\hline cem. $22-3$ & same & ash layer, top & 31 & -4.66 & -4.13 \\
\hline cem. $23-1$ & Hanklit, loose, +22 to +35 & diatomite, lam. & 88 & -19.59 & -2.42 \\
\hline cem. 23-2 & same & ash layer, top & 53 & -20.70 & -2.47 \\
\hline cem. 23-3 & same & ash layer, bottom & 52 & -20.36 & -2.55 \\
\hline cem. 24-1 & Hanklit, loose, +22 to +35 & diatomite, lam., marg. & 87 & -13.11 & -0.99 \\
\hline cem. $24-2$ & same & diatomite, lam., centre & 87 & -14.00 & -0.90 \\
\hline cem. $24-3$ & same & ash layer, centre & 44 & -13.99 & -0.76 \\
\hline cem. $24-4$ & same & diatomite, lam., centre & 83 & -14.48 & -1.17 \\
\hline cem. $24-5$ & same & diatomite, lam., marg.l & 87 & -16.21 & -1.05 \\
\hline cem. $25-1$ & Fegge, $+101 /+102$ & diatomite, lam. & 66 & -17.66 & -0.44 \\
\hline cem. $26-1$ & Skarrehage south, -11 to +1 & diatomite, weakly lam. & 93 & -11.51 & -1.48 \\
\hline cem. $26-2$ & same & diatom., weakly lam., marg. & 91 & -11.11 & -0.97 \\
\hline cem. $26-3$ & same & diatom., weakly lam., marg. & 90 & -10.68 & -0.77 \\
\hline cem. $26-4$ & same & diatom., weakly lam., marg. & 92 & -12.02 & -1.09 \\
\hline cem. $27-1$ & Skarrehage south, below +19 & diatom., lam. & 86 & -20.75 & -2.19 \\
\hline cem. 28-1 & Skarrehage south, +62 & ash layer & 38 & -21.06 & -2.23 \\
\hline cem. $29-1$ & Skarrehage south, $+101 /+102$ & ash layer & 42 & -3.04 & -4.46 \\
\hline cem. $30-1$ & Skarrehage south, +22 to +35 & diatomite, lam., top & 89 & -18.88 & -2.42 \\
\hline cem. $30-2$ & same & diatomite, lam., centre & 94 & -19.39 & -2.65 \\
\hline cem. $30-3$ & same & diatomite, lam., bottom & 72 & -20.95 & -2.16 \\
\hline
\end{tabular}

1) All isotopic values relative to the PDB standard, n.d.: no determination

To be continued... 
Table 1. Geochemical results - Continued

\begin{tabular}{|c|c|c|c|c|c|}
\hline Sample & $\begin{array}{l}\text { Location, } \\
\text { numbers refer to ash layers }\end{array}$ & $\begin{array}{l}\text { Host lithology, } \\
\text { place in concretion }\end{array}$ & $\begin{array}{l}\mathrm{CaCO}_{3} \\
\mathrm{wt} \%\end{array}$ & $\begin{array}{l}\delta^{13} \mathrm{C} \\
\% o^{1)}\end{array}$ & $\begin{array}{l}\delta^{18} \mathrm{O} \\
\% 0^{1)}\end{array}$ \\
\hline cem.31-1 & Ejerslev, -11 to +1 & diatomite, weakly lam. & 82 & -15.83 & -1.15 \\
\hline cem.32-1 & Ejerslev, fragm., below +19 & diatomite, lam. & 91 & -18.15 & -2.32 \\
\hline cem.32-2 & same & diatomite, lam. & 89 & -19.48 & -2.19 \\
\hline cem.33-1 & Ejerslev, fragm., below +19 & diatomite, lam. & 91 & -18.87 & -2.54 \\
\hline cem.33-2 & same & diatomite, lam. & 72 & -18.75 & -2.53 \\
\hline cem.35-1 & Harhøj west, +58 & ash layer & 48 & -21.88 & -2.39 \\
\hline cem. $35-2$ & same & ash layer & 52 & -21.27 & -2.12 \\
\hline cem.36-1 & Harhøj west, +62 & ash layer & 42 & -22.97 & -2.21 \\
\hline cem.37-1 & Harhøj west, +101 & ash layer & 43 & -13.11 & -0.53 \\
\hline cem.37-2 & same & ash layer & 42 & -13.02 & -0.63 \\
\hline
\end{tabular}

"All isotopic values relative to the PDB standard

Thus, initial porosity of the diatomite was high. The decrease in porosity shows that compaction progressed during growth of the concretion. Present porosity of the diatomite is roughly estimated to values around $60 \%$. Cemented ash layers typically have much lower carbonate contents (about 40-50 wt\%) reflecting the lower initial porosity of the sand sized volcanic ash.

\section{Sources of carbon in concretions}

In general, dissolved inorganic carbon (DIC) in pore water formed by bacterial decomposition of organic matter is isotopically depleted, with $\delta^{13} \mathrm{C}$ values close to $-25 \%$ o (Raiswell 1976, Deines 1980). In contrast,
DIC in sea water is isotopically enriched, with $\delta^{13} \mathrm{C}$ values of $-2 \%$ o to $+2 \%$ of recting equilibrium fractionation with atmospheric $\mathrm{CO}_{2}$ (Emrich, Ehhalt \& Vogel 1970).

$\delta^{13} \mathrm{C}$-values of the investigated concretionary carbonates vary from $-24 \%$ o to $-3 \%$ (Table 1 and Figs. 3 and 4). In several cases, pairs of analyses were made on samples representing the centre and the margin of concretions. No systematic variations were observed in these pairs. The most ${ }^{13} \mathrm{C}$-depleted compositions $(-24 \%$ o to $-20 \%$ o are recorded from cemented ash layers and from the calcite-replaced glendonite-like crystals. Samples from cemented diatomite show a range of $\delta^{13} \mathrm{C}$-values from $-23 \%$ to $-6 \%$. These values are intermediate between a pure bacterial and a pure sea
Fig. 4. Frequency plot of $\delta^{13} \mathrm{C}$ values in all samples. It is seen that the carbonate in the concretions consists of a mixture from two sources of which the bacterial is dominant. Carbon isotope composition in \%o deviation from the PDB standard.

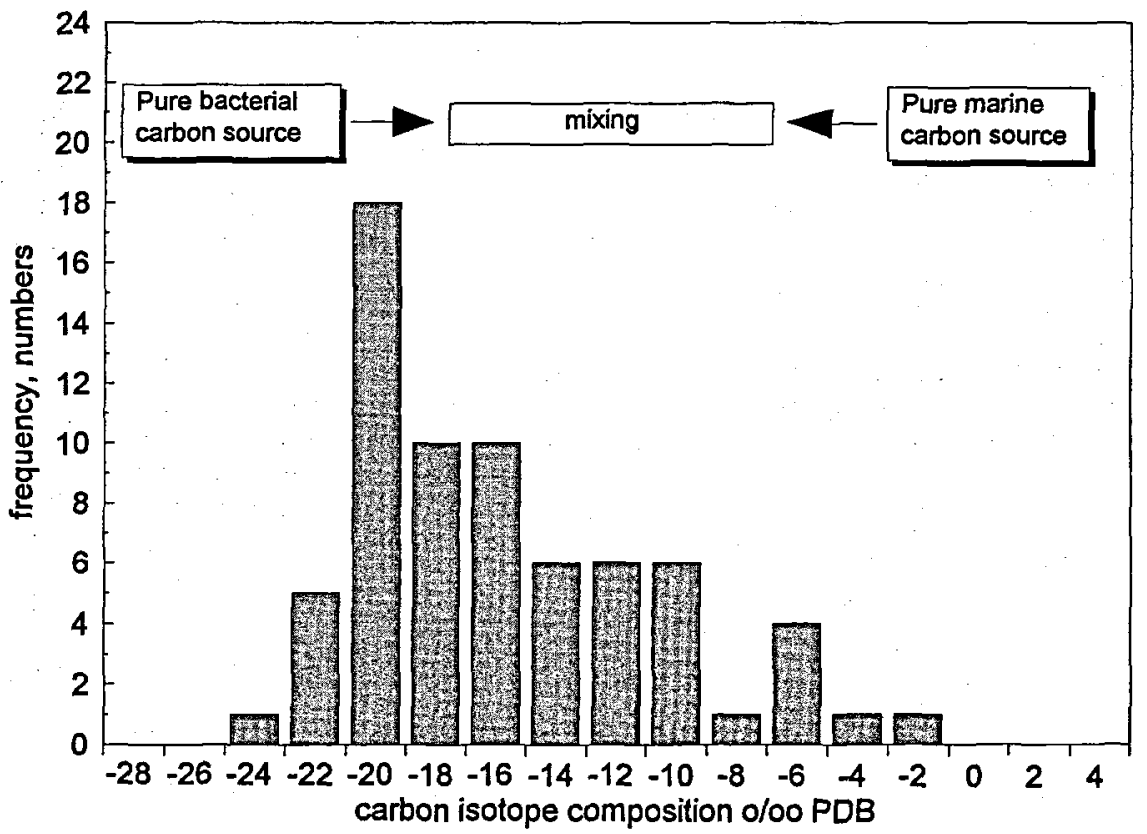




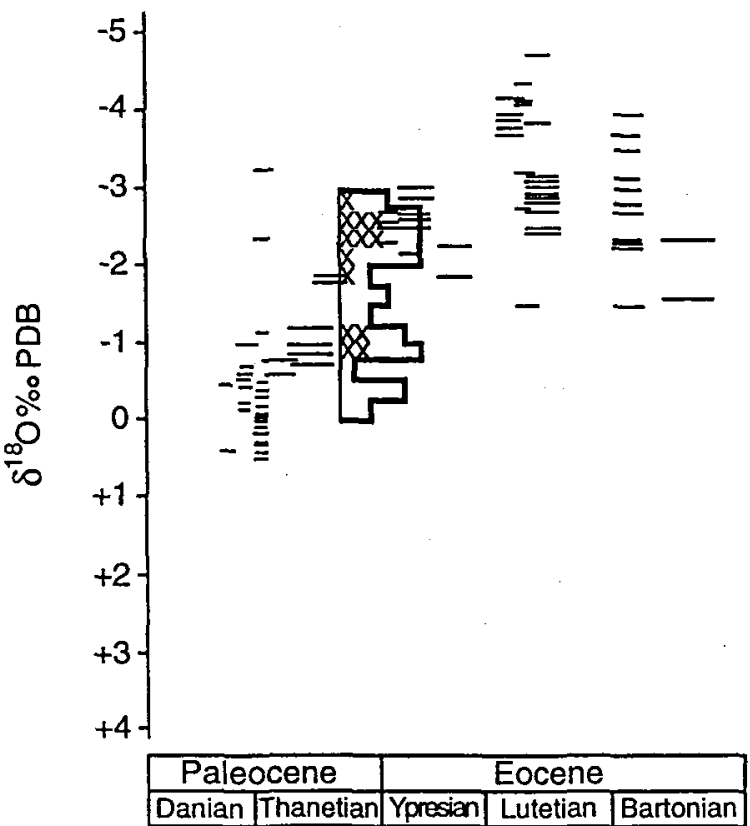

Fig. 5. Plot of measured $\delta^{18} \mathrm{O}$ values in samples of laminated diatomite in concretions (box, $\mathrm{N}=41$ ). Crosses indicate measurements from one level (ash layers +22 and +35 , $\mathrm{N}=13$ ). The measured $\delta^{18} \mathrm{O}$ values are compared to palaeotemperature data from Buchardt (1978) shown as horizontal bars. $\delta^{18} \mathrm{O}$ values of $-1 \%$ agree with Upper Paleocene marine carbonate, values of $-2.5 \%$ agree with Lower Eocene marine carbonate. Stratigraphic subdivision from Buchardt (1978) is retained.

water carbonate. As seen from Fig. 4, bacterial carbonate seems to dominated as carbon source in most concretions.

\section{Oxygen isotopes}

$\delta^{18} \mathrm{O}$-measurements of concretionary carbonate vary between $-4 \% \circ$ and $0 \%$ PDB with the majority of the results between $-3 \%$ and $-1 \%$ (Table 1 and Fig. 3). There is no systematic variation from centre to margin of individual concretions or in the $\delta^{18} \mathrm{O}$-values from bottom to top of the Fur Formation.

\section{Discussion}

The precipitation of calcite in pore spaces is controlled by the concentrations of bicarbonate and calcium ions. As seen from the carbon isotope composition, most of the bicarbonate originated from microbial decomposition of organic matter, supposedly by sulphatereducing bacteria. The simultaneously produced sul- phide was precipitated as framboidal pyrite in the diatomite both outside and inside the concretions. The amount of pyrite has not been measured, but inspection of thin sections indicates a pyrite content of approximately $1 \%$. Pyritized fossils have not been reported from the Fur Formation.

Increased pore water alkalinity from sulphate reduction is a well known phenomena in organic-rich deposits (Suess et al 1982, Buchardt \& Holmes 1995). However, in order to precipitate this alkalinity as calcareous cement, high and continuous supply of calcium ions is a prerequisite. The major components of the diatomite are opaline diatom frustules and smectite, both of which release negligible amounts of calcium ions to the pore water. Calcium therefore had to come from one of the following sources 1) sea water, 2) pore water dissolution of skeletal material from fish and invertebrates, 3) volcanic dust leached into pore water. The sand-sized particles of volcanic glass in the ash layers show no signs of dissolution (Pedersen et al. 1975) and presumably did not contribute to the calcium budget.

Modern sea water contains 0.026 mole $\mathrm{SO}_{4}^{2-}$ and $0.01 \mathrm{~mole} \mathrm{Ca}^{++}$. During sulphate reduction two bicarbonate ions are produced for every sulphate ion being reduced. Assuming a Paleogene sea water composition similar to the modern, it is seen that calcium ions from sea water will be depleted during calcite precipitation prior to exhaustion of sulphate. The Fur Formation is devoid of calcareous microfossils and impressions of bivalves are very rare. Bøggild (1918) suggested that shell carbonate was intermittently produced in large amounts and that later dissolution of this carbonate led to local supersaturation and precipitation of concretions. This interpretation is not supported by the carbon isotope values. The amount of calcium ions from dissolution of fish bones is difficult to estimate but may well have contributed to the total $\mathrm{Ca}$-budget.

Volcanic dust is not observed as a constituent of the diatomite. This, however, does not preclude that claysized volcanic glass was deposited and subsequently leached into the pore water. Most of the recognizable ash layers are of a tholeiitic composition and contain $10 \% \mathrm{CaO}$ (Pedersen et al. 1975). Volcanic dust of a comparable composition is thus a possible contributor to the Ca-budget.

The sedimentological observations show that neither the degree of lamination nor the number or thickness of ash layers are important in location of concretions. Consequently, other factors must have determined the distribution of concretions. Fossils are found in the centre of some but far from all concretions and only contributed to initiate nucleation in some cases. Other factors must have influenced the concretion nucleation such as blooms of calcareous plankton supplying both organic carbon and $\mathrm{CaCO}_{3}$ to the sea floor, or short salinity crises, which killed the diatoms and resulted in a brief increase in organic matter supply to the sediment. Such short salinity fluctuations have re- 
cently been documented by Schmitz et al. (1996) from the overlying Røsnæs Clay Formation. It is tentatively suggested that the concretions were located at levels in the diatomite which received extraordinary amounts of organic matter of pelagic origin.

\section{Palaeotemperatures}

The concretionary $\delta^{18} \mathrm{O}$-values (Fig. 5) are in close agreement with values measured on marine benthic invertebrates of latest Paleocene or earliest Eocene age (Buchardt 1978). He showed that the average $\delta^{18} \mathrm{O}$ of mollusc shell carbonate is about $-1 \%$ in late Paleocene samples and about $-2.5 \%$ in early Eocene samples. The stable oxygen isotope composition is temperature dependent and this range corresponds to a temperature difference of $6^{\circ} \mathrm{C}$. As stated above, the concretions probably formed at shallow depth beneath the sea floor. The temperature here equals the annual average temperature at the sea floor. Consequently the scatter in $\delta^{18} \mathrm{O}$-values in excess of $1.5 \% \circ\left(=6^{\circ} \mathrm{C}\right)$ requires an additional explanation. The three most likely explanations are 1) concretionary growth in equilibrium with pore water in different stages of evolution, 2) short term climatic fluctuations affecting oceanic circulation and bottom water temperature (Zachos et al. 1993), and 3) salinity related ${ }^{18} \mathrm{O}$-variations in the semi-enclosed North Sea Basin.

We tentatively interpret the observed $\delta^{18} \mathrm{O}$-variations as caused by fluctuations in climate and/or salinity. The shallow depth of concretion growth excludes pore water evolution as an important factor. Short term salinity variations in the early Eocene North Sea have recently been proposed by Schmitz el al. (1996) based on ${ }^{18} \mathrm{O}$-variations observed in foraminifers from the Røsnæs Clay Formation.

\section{Conclusions}

From the study of the calcareous concretions (cementsten) in the Fur Formation we have concluded:

1.The concretions formed through precipitation of $\mathrm{CaCO}_{3}$ in the pore spaces of a marine, clayey diatomite.

2. The concretions are an early diagenetic phase formed when the porosity was high (more than $70 \%$ ) and the pore water had the same temperature as the bottom water.

3. The concretions formed from bicarbonate mostly produced by bacterial sulphate reduction of organic matter. Any shell carbonate in the diatomite is dissolved. Rare occurrences of invertebrate shells are found inside concretions.

4. The concretions occur at well constrained stratigraphic levels but in differing sedimentary facies. It is suggested that the concretions were located at levels in the diatomite which received extraordinary amounts of organic matter of pelagic origin.

5. We interpret the observed $\delta^{18} \mathrm{O}$-variations as caused by local short term fluctuations in climate and/or salinity.

\section{Dansk sammendrag}

Fur Formationen er kendt for sit indhold af cementsten, idet disse kalkkonkretioner lokalt indeholder fossiler med en fremragende bevaringstilstand. Unders $\emptyset$ gelsen af de stabile kulstof- og iltisotoper i den calcit, som opbygger konkretionerne, viser at karbonaten overvejende er af bakteriel oprindelse. Denne tolkning bygger på målte $\delta^{13} \mathrm{C}$ værdier, karakteristisk $-16 \%$ til $-20 \%$ o $\mathrm{PDB}$, som repræsenterer en blanding mellem bakterielt producerede bikarbonationer $\left(\delta^{13} \mathrm{C}=-25 \%\right.$ o og bikarbonationer fra havvand $\left(\delta^{13} \mathrm{C}=0 \%\right.$ ) .

De målte $\delta^{18} \mathrm{O}$ værdier stemmer overens med dem, der tidligere er målt på aragonitskallede marine invertebrater fra Nords $\varnothing$ bassinet fra samme tidsperiode. Denne overensstemmelse tolkes som indicerende, at dannelse af konkretionskarbonat er sket ved samme temperaturer og derfor i lav dybde i havbunden.

Fur Formationens askelags-stratigrafi viser, at cementstenene optræder i bestemte stratigrafiske niveauer. Sedimentologiske unders $\emptyset$ gelser viser, at cementstenene optræder $\mathbf{i}$ såvel lamineret som strukturløst moler og såvel i niveauer med tykke, tætliggende askelag som niveauer uden askelag. Dannelsen af cementstenene synes således hverken at være bestemt af de sedimentære facies (mængden af ilt $\mathrm{i}$ porevandet) eller af tilstedeværelsen af askelag. Det foreslås derfor, at episodiske tilførsler af organisk materiale, f. eks. i form af phytoplankton, gjorde bestemte stratigrafiske niveauer til de foretrukne steder for vækst af cementstenskonkretionerne.

\section{Acknowledgements}

The results were first presented at the symposium 'Geology of the Mo-Clay' on Mors June 13-15th 1994, organized by S. Schack Pedersen, the Geological Survey of Denmark. Dr. R. W. O'B. Knox kindly corrected the English and an anonymous referee provided numerous helpful suggestions. Birte Warming and Inge Juul carried out the laboratory work at the Stable Isotope Laboratory, Danish Centre of Isotope Geology. 


\section{References}

Andersen, S. A. 1937: De vulkanske Askelag i Vejgennemskæringen ved Ølst og deres Udbredelse i Danmark. Danmarks Geologiske Unders $\varnothing$ gelse, 2. Række 59, 50 pp.

Buchardt, B. 1978: Oxygen isotope palaeotemperatures from the Tertiary period in the North Sea area. Nature 275, 121123.

Buchardt, B. \& Holmes, M. A. 1995: Initial transgressive phase of Leg 144 guyots: evidence of extreme sulfate reduction. In Haggerty, J.A., Premoli Silva, I., Rack. F, and McNutt, M. K. (Eds), Proc. ODP, Sci. Results, 144. College Station, TX (Ocean Drilling Program), 895-914.

Bøggild, O. B. 1918: Den vulkanske aske i Moleret. Danmarks geologiske Undersøgelse, Ser. 2, 33, 84 pp.

Deines, P. 1980: The isotopic composition of reduced organic carbon. In Fritz, P. \& Fontes, J.Chr. (eds.), Handbook of Environmental Isotope Geology. Vol. 1: The Terrestrial Environment: Amsterdam (Elsevier), 329-406.

Emrich, K., Ehhalt, D. H. \& Vogel, J. C. 1970: Carbon isotope fractionation during precipitation of calcium carbonate. Earth and Planetary Science Letters 8, 363-371.

Gry, H. 1940: De istektoniske Forhold i Moleromraadet. Med Bemærkninger om vore dislocerede Klinters Dannelse og om den negative Askeserie. Meddelelser Dansk Geologisk Forening 9, 586-627.

Heilmann-Clausen, C. 1995: Palæogene aflejringer over Danskekalken. I O. B.Nielsen (ed.) Danmarks geologi fra Kridt til i dag. Aarhus Geokompendier 1, 70-113.

Knox, R. W. O'B. 1984: Nannoplankton zonation and the Paleocene/Eocene boundary beds of NW Europe: an indirect correlation by means of volcanic ash layers. Journal Geological Society of London 141, 993-999.

Know, R. W. O'B., Corfield, R. \& Dunat, R. E. 1996: Correlation of the Early Paleogene in Northwest Europe. Geological Society Special Publication No. 101. London.

McCrea, J. M. 1950: On the isotopic chemistry of carbonates and a paleotemerature scale. Journal of Chemical Physics 18 849-857.

Pedersen, A. K., Engell, J. \& Rønsbo, J. G. 1975: Early Tertiary volcanism in the Skagerrak: new chemical evidence from ash layers in the Mo-clay of northern Denmark. Lithos 8, 255-268.

Pedersen, G. K. 1978: Molerets Sedimentologi. Unpublished thesis, University of Copenhagen.

Pedersen, G. K. 1981: Anoxic events during sedimentation of a Paleogene diatomite in Denmark. Sedimentology 28, 487-504.

Pedersen, G. K. \& Surlyk, F. 1983: The Fur Formation, a late Paleocene ash-bearing diatomite from northern Denmark. Bulletin of the Geological Society of Denmark 32, 43-65.

Pedersen, S. S., Pedersen, G. K. \& Noe, P. 1994: Mo-clay on Mors. Mors $\emptyset$ Lokalhistoriske Forlag. 48 pp.

Raiswell, R. 1971: The growth of Cambrian and Liassic concretions. Sedimentology 17, 147-171.

Raiswell, R. 1976: The microbial formation of carbonate concretions in the Upper lias of NE England. Chemical Geology 18, 227-244.

Shearmann, D. J. \& Smith, A. J. 1985: Ikaite, the parent mineral of jarrowite-type pseudomorphs. Proceedings of the Geological Association 96, 305-314.

Schmitz, B., Heilmann-Clausen, C., King, C., Steurbaut, E., Andreasson, F. P., Corfield, R. M. \& Cartlidge, J. E. 1996: Stable isotope and biotic evolution in the North Sea dur- ing the early Eocene: the Albæk Hoved section, Denmark. In Knox, R. W. O’B., Corfield, R. \& Dunat, R.E. (Eds): Correlation of the Early Paleogene in Northwest Europe. Geological Society Special Publication No. 101, 275-306. Suess, E., Balzer, W., Hesse, K.-F., Müller, P. J., Ungerer, P. J. \& Wefer, G. 1982: Calcium carbonate hexahydrate from organic-rich sediments of the Antarctic Shelf: Precursor of glendonites. Science 1216, 1128-1131.

Zachos, J. C., Lohmann, K. C., Walker, J. C. G. \& Wise, S. W. 1993: Abrubt climate change and transient climates during the Paleogene: A marine perspective. Journal of Geology 101, 191-213.

Ziegler, P. A. 1990: Geological Atlas of Western and Central Europe. 2nd edition. Shell Internationale Petroleum Maatschippij B.V., Den Haag, 239 pp. 